\title{
Nerve Growth Factor Treatment Increases Brain-Derived Neurotrophic Factor Selectively in TrkA-Expressing Dorsal Root Ganglion Cells and in Their Central Terminations within the Spinal Cord
}

\author{
G. J. Michael, ${ }^{1}$ S. Averill,, ${ }^{1}$ A. Nitkunan, ${ }^{2}$ M. Rattray, ${ }^{3}$ D. L. H. Bennett ${ }^{2}$, Q. Yan, ${ }^{4}$ and J. V. Priestley ${ }^{1}$ \\ ${ }^{1}$ Department of Anatomy, Faculty of Basic Medical Sciences, Queen Mary and Westfield College, London 31 4NS, United \\ Kingdom, Departments of 2Physiology and 'BBiochemistry, United Medical and Dental Schools, St. Thomas's Hospital \\ Medical School Campus, London SE1 7EH, United Kingdom, and ${ }^{4}$ Amgen Inc., Amgen Centre, Thousand Oaks, \\ California 91320-1789
}

Using immunocytochemistry and in situ hybridization, we have examined the expression of brain-derived neurotrophic factor (BDNF) and of neurotrophin receptors in dorsal root ganglion cells. In the adult rat, BDNF mRNA and protein were found mainly in the subpopulation of cells that express the nerve growth factor (NGF) receptor trkA and the neuropeptide calcitonin gene-related peptide (CGRP). NGF increased BDNF within the trkA/CGRP cells to the extent that almost $90 \%$ of trkA cells contained BDNF mRNA after intrathecal NGF treatment, and $80-90 \%$ of BDNF-expressing cells contained trkA. Non-trkA cells that expressed BDNF included some trkC cells and some small cells that labeled with the lectin Griffonia simplicifolia IB4, a marker for cells that do not express trks. However, very few trkB cells expressed either BDNF mRNA or protein, and NGF did not increase BDNF expression in non-trkA cells. BDNF protein was anterogradely transported both periph- erally and centrally. The central transport resulted in BDNF immunoreactivity in CGRP containing terminal arbors in the dorsal horn of the spinal cord, and this immunoreactivity was increased by NGF treatment. Electron microscopic analysis revealed that the BDNF immunoreactivity was present in finely myelinated and unmyelinated axons and in axon terminals, where it was most concentrated over dense-cored vesicles.

Our data do not support an autocrine or paracrine role for BDNF within normal dorsal root ganglia, but indicate that BDNF may act as an anterograde trophic messenger. NGF levels in the periphery could influence dorsal horn neurons via release of BDNF from primary afferents.

Key words: brain-derived neurotrophic factor; $m R N A$; trkA; trkB; NGF; dorsal root ganglion cells; primary afferent; calcitonin gene-related peptide
Brain-derived neurotrophic factor (BDNF) is a member of a small family of related molecules termed neurotrophins, the other mammalian members being nerve growth factor (NGF), neurotrophin (NT)-3, and NT-4/5. The neurotrophins exert their effects through a family of tyrosine kinase (trk) receptors comprising trkA (selective for NGF), trkB (selective for BDNF and NT-4/5), and trkC (selective for NT-3) (for review, see Maness et al., 1994).

All three trks are expressed within adult dorsal root ganglia (McMahon et al.,1994; Kashiba et al., 1995; Wright and Snider, 1995), and all members of the neurotrophin family show retrograde transport to dorsal root ganglia from peripheral nerves (DiStefano et al., 1992; Curtis et al., 1995). BDNF, however, is unusual in being also produced by adult dorsal root ganglion (DRG) cells (Ernfors et al., 1990, 1993; Wetmore and Olson, 1995; Apfel al., 1996; Cho et al., 1997), although the role of this BDNF is not known. An autocrine role has been proposed on the

Received April 23, 1997; revised July 21, 1997; accepted Aug. 12, 1997.

This work was supported by the Medical Research Council (UK) and the Wellcome Trust. We thank Professor J. M. Polak and Dr. D. O. Clary for provision of rabbit CGRP and trkA antibodies. Human recombinant NGF was a generous gift of Genentech Inc.

Correspondence should be addressed to Professor J. V. Priestley, Department of Anatomy, Faculty of Basic Medical Sciences, Queen Mary and Westfield College, Mile End Road, London E1 4NS, UK.

Copyright (C) 1997 Society for Neuroscience $0270-6474 / 97 / 178476-15 \$ 05.00 / 0$ basis of studies of single-neuron microcultures (Acheson et al., 1995). Alternatively, BDNF protein has been suggested to be released locally to act in a paracrine manner on trkB cells (Apfel et al., 1996); however, there is little information regarding the dorsal root ganglion (DRG) subtypes that synthesize BDNF. Two studies have recently reported that NGF increases BDNF mRNA in trkA-expressing cells (Apfel et al., 1996; Cho et al., 1997), but it is not known whether trkB or trkC cells synthesize BDNF. It is also not known how the expression of BDNF protein and/or mRNA relates to subgroups of DRG cells defined according to widely used neurochemical criteria (Hunt et al., 1992; Lawson, 1992). BDNF is axonally transported by DRG cells to their central and/or peripheral processes (Zhou and Rush, 1996), but the cell type involved is not known.

The role of BDNF in DRG cells is given added importance by the fact that BDNF synthesis is greatly increased after nerve injury (Ernfors et al., 1993). Nerve damage causes the central terminals of large-diameter DRG cells to sprout within the dorsal horn (Woolf et al., 1992), and this sprouting can be prevented by NGF treatment (Bennett et al., 1996a). The stimulus for the sprouting is not known, but it has been suggested that it might be in response to BDNF released from the terminals of smalldiameter DRG cells (Mannion et al., 1996). BDNF released from primary afferents might have profound effects on both spinal cord anatomy and physiology. 

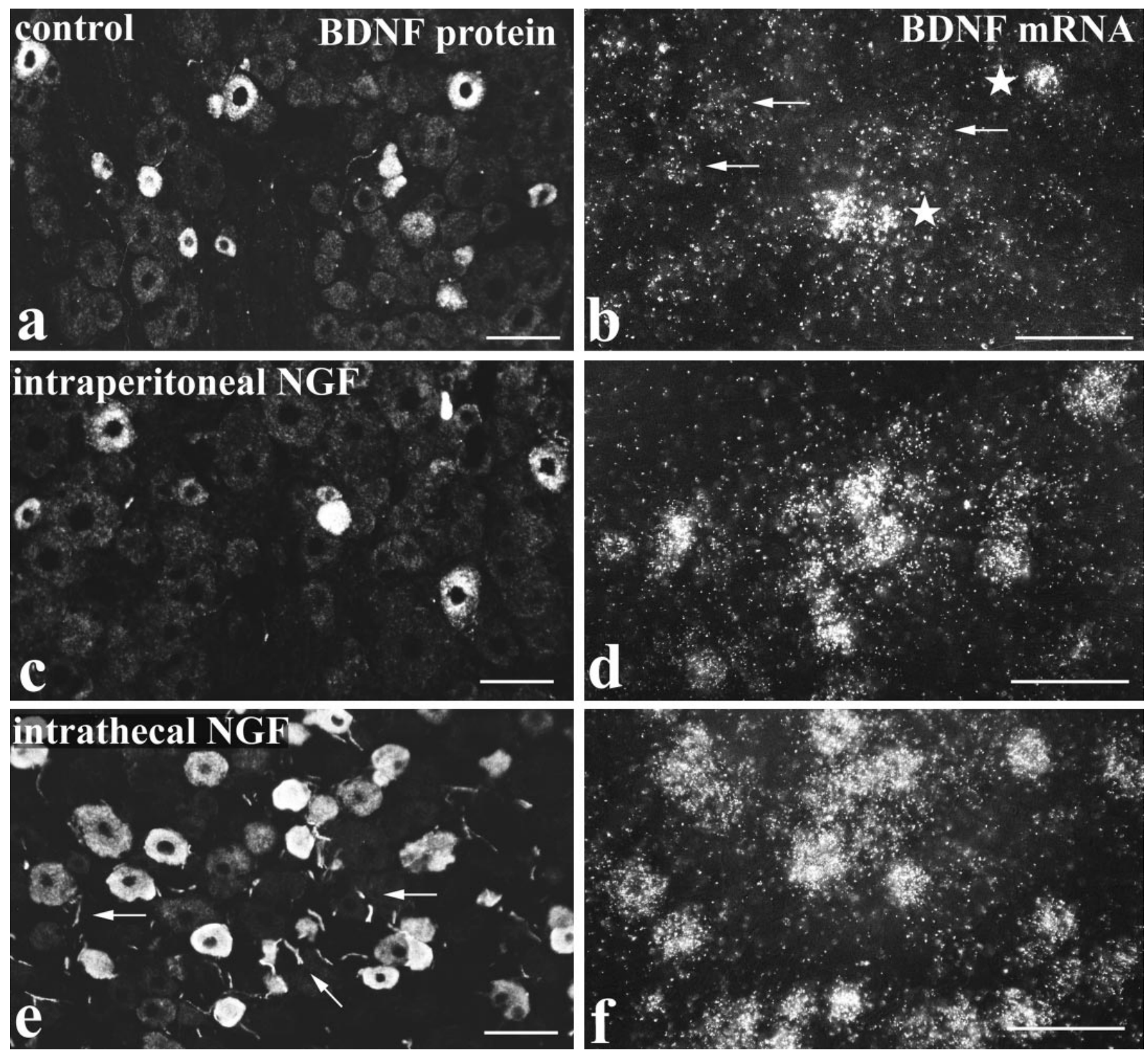

Figure 1. BDNF mRNA and protein are increased by NGF treatment. BDNF immunofluorescence $(a, c, e)$ and in situ hybridization $(b, d, f)$ in lumbar ganglia of control $(a, b)$, intraperitoneal NGF-treated $(c, d)$, and intrathecal NGF-treated $(e, f)$ rats. BDNF immunoreactivity is present in small to medium sized DRG cells and is increased after NGF treatment. The increase is most evident after intrathecal NGF $(e)$, where immunoreactivity is seen not only in a larger number of DRG cells but also in neighboring axons (arrows). NGF treatment also increases expression of BDNF mRNA. In control tissue $(b)$, a few heavily labeled cells are seen (stars) together with scattered light labeling (arrows). The number of heavily labeled cells is increased after intraperitoneal NGF $(d)$ and increased even more by intrathecal NGF $(f)$. Scale bars, $100 \mu \mathrm{m}$.

To clarify some of these issues we have used in situ hybridization and immunocytochemistry to establish the DRG cell types that express BDNF and the changes that take place in response to systemic or intrathecal NGF. We have also examined axonal transport of BDNF protein, its distribution in the spinal cord, and its subcellular location within axon terminals.

A preliminary report of some of this work has been published previously in abstract form (Priestley et al., 1996).

\section{MATERIALS AND METHODS}

Tissue preparation. A total of 18 adult male Wistar rats $(200-400 \mathrm{gm}$ body weight) were processed for BDNF immunocytochemistry or in situ hybridization. Four of these had $1 \mathrm{mg} / \mathrm{kg}$ intraperitoneal injections of recombinant human NGF 13 or $24 \mathrm{hr}$ before perfusion, four had intra-
Table 1. The effect of intraperitoneal NGF (IP NGF) or intrathecal NGF on the percentage of DRG cells expressing BDNF mRNA, BDNF immunoreactivity, or trkA immunoreactivity

\begin{tabular}{rllr} 
& Control & IP NGF & Intrathecal NGF \\
\hline BDNF immu- & & & \\
noreactivity & $22.3 \pm 1.2 \%(3)$ & $22.3 \pm 3.3 \%(3)$ & $40 \pm 1.5 \%(4)^{* *}$ \\
BDNF mRNA & $28.5 \pm 3.3 \%(4)$ & $43.7 \pm 4.4 \%(3)^{*}$ & $37.8 \pm 1.4 \%(4)^{*}$ \\
$\begin{array}{c}\text { TrkA immu- } \\
\text { noreactivity }\end{array}$ & $37.8 \pm 2.2 \%(4)$ & $37.5 \pm 2.0 \%(4)$ & $42.3 \pm 3.1 \%(3)$
\end{tabular}

The figures in brackets indicate the number of animals analyzed. * indicates significantly different from controls at $p<0.05$; ** indicates $p<0.001$. 

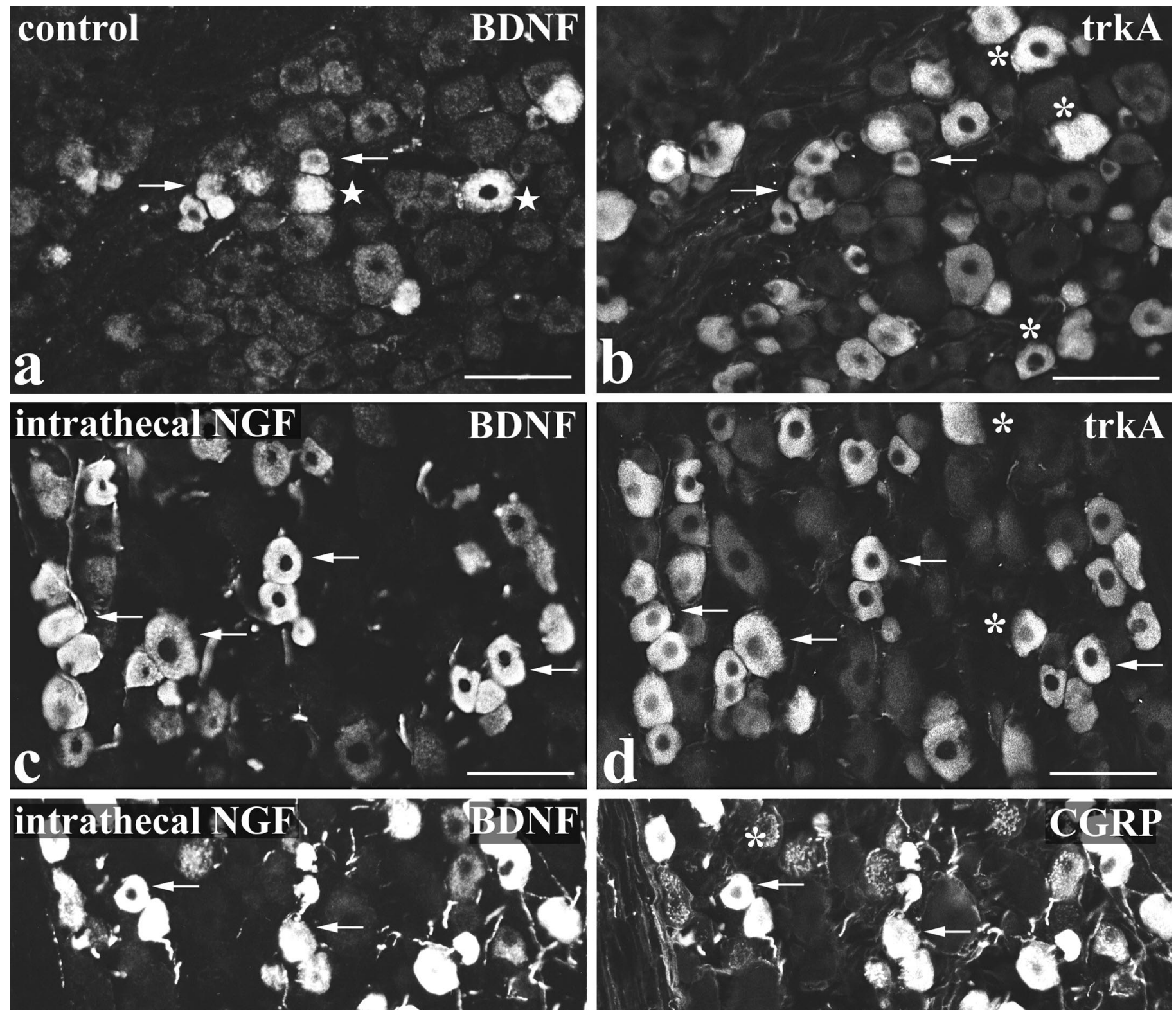

Q
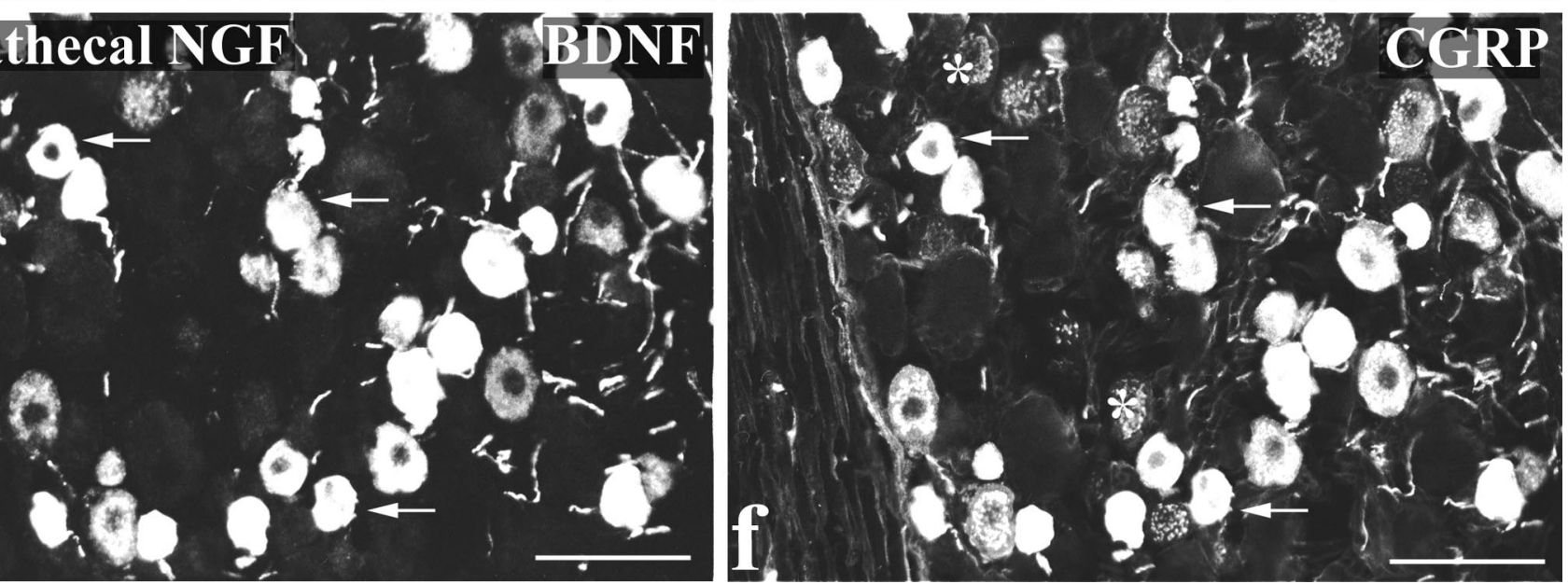

Figure 2. BDNF immunoreactivity is present in trkA/CGRP cells and is increased by NGF treatment. Double-labeling for BDNF ( $a, c, e)$ and either trkA $(b, d)$ or CGRP $(f)$ immunofluorescence in lumbar ganglia of control $(a, b)$ and intrathecal NGF-treated $(c-f)$ rats is shown. In both control and intrathecally treated animals, the majority of BDNF-immunoreactive DRG cells are also trkA immunoreactive $(a-d)$. However, because intrathecal NGF increases the level of BDNF immunoreactivity, the number of trkA-immunoreactive cells that double-label for BDNF is increased in $c$ and $d$ compared with $a$ and $b$. A similar situation occurs for BDNF and CGRP double-labeling, with extensive coexistence of BDNF and CGRP evident after intrathecal NGF treatment $(e, f)$. Arrows indicate BDNF/trkA or BDNF/CGRP double-labeled cells; asterisks indicate cells single-labeled for trkA or CGRP; stars indicate cells single-labeled for BDNF. Scale bars, $100 \mu \mathrm{m}$.

thecal NGF, and five had unilateral ligations of dorsal roots or sciatic nerves.

Intrathecal delivery of NGF was performed basically as described previously (Bennett et al., 1996a). A laminectomy of the L5 and L6 vertebrae was performed under pentobarbitone anesthesia (Sagatal, Rhône Mérieux Ltd., UK) (40 mg/kg, i.p.). The dura was cut, and a
SILASTIC tube ( $0.6 \mathrm{~mm}$ diameter) was passed intrathecally so that its tip lay over the lumbar enlargement. Alternatively, a tube was introduced through the foramen magnum and passed intrathecally to lie over the cervical cord. NGF $(1 \mathrm{mg} / \mathrm{ml}$ in saline $)$ was infused using a mini-osmotic pump (Alzet type 2002, Alza Corp., Palo Alto, CA) at a rate of $0.5 \mu \mathrm{l} / \mathrm{hr}$ for a period of 1-2 weeks. For ligation of dorsal roots, a laminectomy of 
Table 2. The effect of intraperitoneal NGF (IP NGF) or intrathecal NGF on the percentage of BDNF-expressing DRG cells that also exhibit trkA or CGRP immunoreactivity

\begin{tabular}{|c|c|c|c|c|c|c|}
\hline & \multicolumn{2}{|l|}{ Control } & \multicolumn{2}{|l|}{ IP NGF } & \multicolumn{2}{|c|}{ Intrathecal NGF } \\
\hline & $\begin{array}{l}\% \text { of BDNF } \\
\text { expressing } \\
\text { other }\end{array}$ & $\begin{array}{l}\% \text { of other } \\
\text { expressing } \\
\text { BDNF }\end{array}$ & $\begin{array}{l}\% \text { of BDNF } \\
\text { expressing } \\
\text { other }\end{array}$ & $\begin{array}{l}\text { \% of other } \\
\text { expressing } \\
\text { BDNF }\end{array}$ & $\begin{array}{l}\% \text { of BDNF } \\
\text { expressing } \\
\text { other }\end{array}$ & $\begin{array}{l}\% \text { of other } \\
\text { expressing } \\
\text { BDNF }\end{array}$ \\
\hline $\begin{array}{l}\text { BDNF and trkA } \\
\text { immunoreactivities }\end{array}$ & $46 \%(200 / 434)$ & $21 \%(200 / 931)$ & $49 \%(207 / 421)$ & $29 \%(207 / 721)$ & $91 \%(201 / 221)$ & $84 \%(201 / 268)$ \\
\hline $\begin{array}{l}\text { BDNF and CGRP } \\
\text { immunoreactivities }\end{array}$ & $68 \%(131 / 192)$ & $20 \%(131 / 644)$ & $44 \%(227 / 511)$ & $21 \%(227 / 1088)$ & $96 \%(322 / 335)$ & $76 \%(322 / 424)$ \\
\hline $\begin{array}{l}\text { BDNF mRNA and trkA } \\
\text { immunoreactivity }\end{array}$ & $44 \%(301 / 507)$ & $30 \%(301 / 810)$ & $80 \%(900 / 1241)$ & $60 \%(900 / 1311)$ & $79 \%(540 / 685)$ & $88 \%(540 / 603)$ \\
\hline
\end{tabular}

The figures in brackets indicate the number of cells counted.

the L2 and L3 vertebrae was performed, and the L4 and L5 roots were tied with a single or double $5 / 0$ silk ligature. For peripheral nerve ligation, the sciatic nerve was exposed under pentobarbitone anesthesia and tied with a single or double 5/0 ligature at midthigh level. Ligation was performed on control rats and on rats that received intraperitoneal NGF $24 \mathrm{hr}$ before ligation. Perfusion was performed 12-24 hr after ligation.

Rats were anesthetized with sodium pentobarbital $(60 \mathrm{mg} / \mathrm{kg})$ and perfused through the ascending aorta with $30 \mathrm{ml}$ vascular rinse followed by 300 $\mathrm{ml} 4 \%$ paraformaldehyde in $0.1 \mathrm{M}$ phosphate buffer. After $2.5-3.0 \mathrm{hr}$ post-fixation, tissue blocks were cryoprotected in $15 \%$ sucrose, and 8-12 $\mu \mathrm{m}$ sections were cut on a cryostat. Sections were then stained using one of the following procedures: light microscopic immunocytochemistry, in situ hybridization, combined immunofluorescence and in situ hybridization, or preembedding electron microscopic immunocytochemistry.

Light microscopic immunocytochemistry. Sections were stained using standard single or dual color indirect labeled immunofluorescence or indirect tyramide signal amplification (TSA) (NEN) fluorescence procedures (Priestley, 1997). Incubations consisted of $1 \mathrm{hr}$ in $10 \%$ normal serum followed by $18-36 \mathrm{hr}$ in primary antibody and $3 \mathrm{hr}$ in developing secondary antisera. For BDNF labeling, an affinity-purified rabbit antibody raised against recombinant human BDNF was used at 1:500 (indirect labeled procedure) or at 1:2000-1:5000 (TSA procedure). For double-labeling, this antibody was combined with one of the following: rabbit or sheep (Affiniti) CGRP polyclonal antisera (1:2000), rabbit polyclonal antiserum directed against the extracellular domain of trkA (code-labeled RTA, used at $2.5 \mu \mathrm{g} / \mathrm{ml}$ ), or Griffonia simplicifolia IB4 lectin (Sigma, Poole, UK), which recognizes terminal $\alpha$-galactose residues $(12.5 \mu \mathrm{g} / \mathrm{ml}$ biotinylated IB4). The characteristics and staining specificity of all these markers have been reported previously (BDNF, Yan et al., 1997; RTA, Clary et al., 1994, Averill et al., 1995; rabbit CGRP, Merighi et al., 1988; goat CGRP and IB4, Averill et al., 1995). Controls for double-labeling included reversing the order of the primary antisera, as well as omitting the first or second primary antiserum. The two sets of antisera were applied sequentially, and this normally involved BDNF TSA followed by indirect labeled immunofluorescence. Although two primary antisera raised in rabbit were sometimes combined, nonspecific double-labeling was not observed. A similar protocol has been used by other workers (Hunyady et al., 1996; Shindler and Roth, 1996), and the lack of cross-reactivity is thought to be attributable to the fact that the TSA procedure allows the first series primary antibody to be used at a dilution that is too high to be detected by the second reagent set. Our data support this explanation. In control single-labeling using indirect labeled immunofluorescence, we were unable to visualize the BDNF antiserum at the dilutions used for the TSA procedure.

Secondary reagents used for indirect immunofluorescence included both FITC- and TRITC-labeled anti-rabbit IgG and anti-sheep IgG affinity-purified antisera (Jackson ImmunoResearch, West Grove, PA) (1:100 dilution) and 1:200 ExtrAvidin-FITC (for IB4 localization; Sig$\mathrm{ma}$ ). TSA labeling was performed using biotinylated goat anti-rabbit IgG (1:400) (Vector, Burlingame, CA) and Vectastain Elite peroxidase reagent (Vector) followed by biotinyl tyramide (NEN TSA-indirect kit) and ExtrAvidin-FITC (1:500, Sigma). After incubation in secondary reagents, sections were washed briefly in PBS and then mounted in PBS/glycerol (1:3) containing 2.5\% 1,4 diazobicyclo $(2,2,2)$ octane (antifading agent; Sigma).
In situ hybridization. Oligonucleotide probes complementary to bases 273-306 of the rat BDNF sequence (Timmusk et al., 1993), bases 124157 of the rat trkA sequence (Meakin et al., 1992), bases 2213-2246 of the rat trkB sequence (Middlemas et al., 1991), and bases 1099-1132 of the rat trkC sequence (Valenzuela et al., 1993) were synthesized (Genosys) and then hybridized to cryostat sections using standard procedures (Michael and Priestley, 1995, 1996a). The trkB probe was directed against a portion of the tyrosine kinase domain and designed only to recognize full length receptors. The probes were labeled at the $3^{\prime}$ end with ${ }^{35}$ S-dATP (Dupont NEN, Wilmington, DE) and terminal transferase (Promega, Madison, WI) to specific activities of $\sim 5000 \mathrm{Ci} / \mathrm{mmol}$. Sections were acetylated in $0.25 \mathrm{M}$ acetic anhydride $/ 0.1 \mathrm{M}$ triethanolamine for $10 \mathrm{~min}$, dehydrated in ethanols $(70-100 \%)$, and delipidated with chloroform. Hybridizations were performed overnight at $37^{\circ} \mathrm{C}$ using probe concentrations of $2 \mathrm{nM}$. Hybridization buffer consisted of $4 \times$ SSC $(1 \times \mathrm{SSC}=150 \mathrm{~mm}$ sodium chloride, $15 \mathrm{~mm}$ sodium citrate, $\mathrm{pH} 7.0), 50 \%$ deionized formamide, $0.04 \%$ Ficoll-400, $0.04 \%$ polyvinylpyrrolidone, $0.04 \%$ bovine serum albumin, $10 \%$ dextran sulfate, $0.1 \%$ SDS, $20 \mathrm{~mm}$ dithiothreitol (DTT), $20 \mu \mathrm{g} / \mathrm{ml}$ yeast tRNA, $100 \mu \mathrm{g} / \mathrm{ml}$ sheared salmon sperm DNA, and $10 \mu \mathrm{g} / \mathrm{ml}$ poly adenylate.

After hybridization, sections received two $(15 \mathrm{~min})$ washes at room temperature (RT) in $2 \times \mathrm{SSC}$, two at $50^{\circ} \mathrm{C}$ in $1 \times \mathrm{SSC}$, and one at $50^{\circ} \mathrm{C}$ in $0.2 \times$ SSC. Sections were washed an additional $2 \mathrm{hr}$ at RT in $1 \times \mathrm{SSC}$, dehydrated through ethanols, dipped in autoradiographic emulsion (Amersham LM1), and exposed for 4-8 weeks. After development, slides were counterstained with toluidine blue, dehydrated, and coverslipped.

In situ hybridization combined with immunofluorescence. Immunofluorescence was followed by oligonucleotide in situ hybridization, as described previously (Priestley et al., 1993; Michael and Priestley, 1996b). Standard indirect immunofluorescence was performed as described above, except that antisera were diluted in diethylpyrocarbonate-treated PBS containing 0.5-5 mM DTT and $100 \mathrm{U} / \mathrm{ml}$ RNasin (Promega) in addition to $0.2 \%$ Triton X-100. After they were immunostained, sections were processed as for single BDNF in situ hybridization, except that developed sections were mounted in PBS/glycerol instead of being toluidine blue-counterstained and dehydrated. Silver grains in PBS/glycerol mounted sections were visualized using epipolarized illumination (Priestley et al., 1993).

Pre-embedding electron microscopic immunocytochemistry. Four animals were perfused with $4 \%$ paraformaldehyde, $0.1 \%$ glutaraldehyde in $0.1 \mathrm{M}$ phosphate buffer and processed for electron microscopic immunocytochemistry using standard preembedding procedures (Priestley et al., 1992). The spinal cord was dissected out, post-fixed 2.5 $\mathrm{hr}$ in the same fixative, and immersed in PBS. Sections $(40 \mu \mathrm{m})$ were cut using a vibratome (Oxford) and pretreated with $1 \%$ sodium borohydride in PBS for 30 min before they were immunostained. Sections were incubated for $30 \mathrm{~min}$ in $10 \%$ normal goat serum and then transferred to BDNF polyclonal antibody $(1: 1000)$ for $12 \mathrm{hr}$ at $4^{\circ} \mathrm{C}$. Primary antibody was subsequently revealed using 1:400 biotinylated goat anti-rabbit IgG (Vector) and Vectastain Elite peroxidase reagent (Vector). Sections were then developed with a solution containing $0.05 \% 3,3^{\prime}$-diaminobenzidine, $0.04 \%\left(\mathrm{NH}_{4}\right)_{2} \mathrm{SO}_{4} \cdot \mathrm{NiSO}_{4}$, and $0.01 \%$ $\mathrm{H}_{2} \mathrm{O}_{2}$ in $0.1 \mathrm{M}$ phosphate buffer, $\mathrm{pH}$ 7.3. Unless stated otherwise, incubations were performed at RT, and antisera were diluted in PBS. Stained sections were then contrasted in $\mathrm{OsO}_{4}(1 \%)$ and uranyl acetate (1\%), dehydrated, and flat-embedded in Durcupan (Fluka, Buchs, 

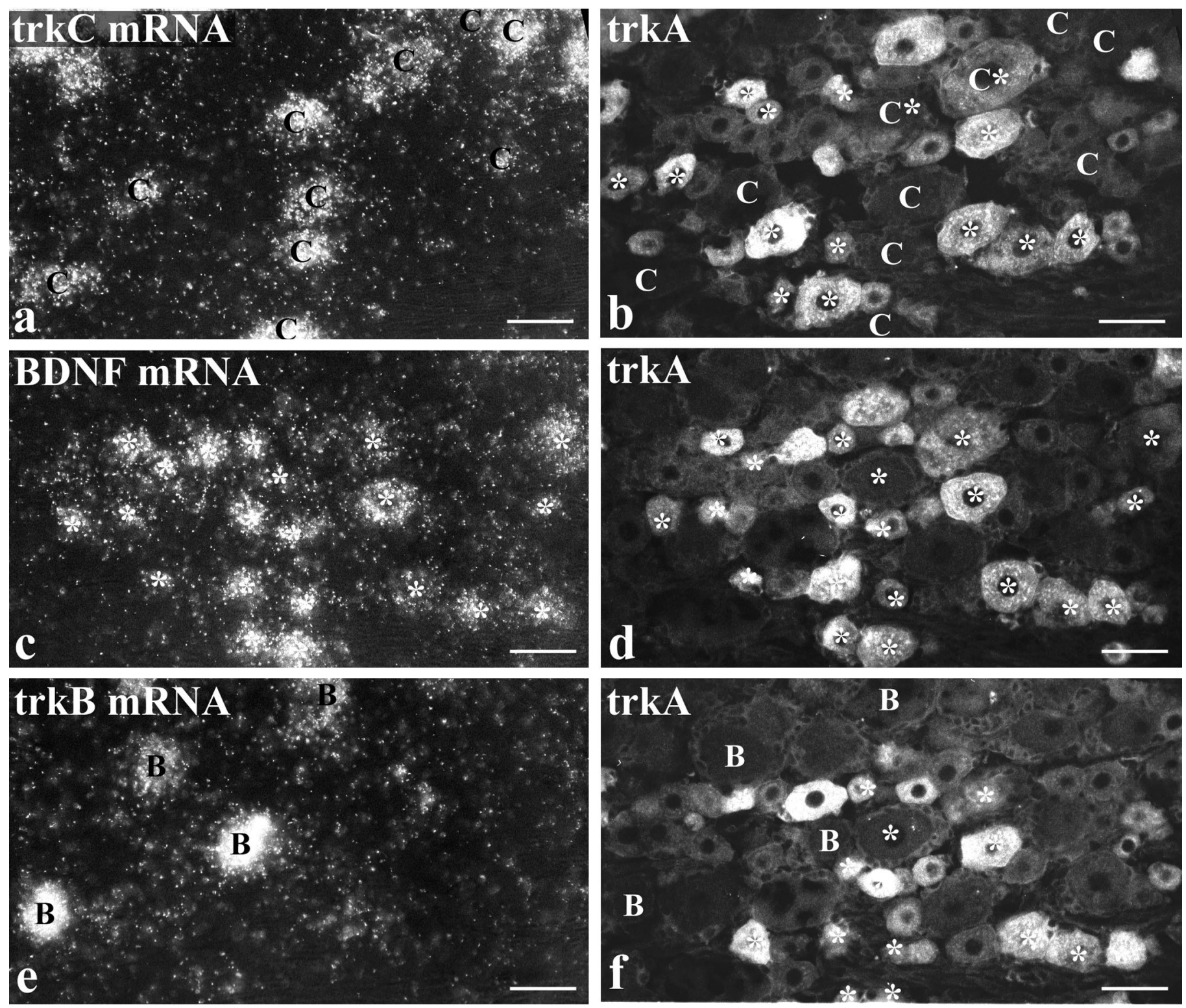

Figure 3. BDNF mRNA is expressed by numerous trkA cells but by few trkB or trkC cells. Intraperitoneal NGF treatment is shown. $a, c$, and $e$ show three serial sections processed for $\operatorname{trkC}(a), \operatorname{BDNF}(c)$, and trkB $(e)$ mRNAs using in situ hybridization. Each section was also immunostained for trkA $(b, d, f)$. Comparison of $c$ and $d$ shows that the majority of cells labeled for BDNF mRNA (asterisks) are also trkA immunoreactive. Those BDNF-labeled cells that are visible in the serial sections $(a, b, e, f)$ are marked by asterisks in $b$ and $f$. Comparison of $a$ and $b$ shows that the majority of trkC-labeled cells (marked $C$ ) do not express BDNF mRNA. However, two BDNF/trkC double-labeled cells are visible in $b$, one of which is trkA immunoreactive. Comparison of $e$ and $f$ allows the distribution of DRG cells that express trkB (marked $B$ ) and BDNF (asterisks) to be compared. They seem to form two discrete populations, and no double-labeled cells are visible. Scale bars, $50 \mu \mathrm{m}$.

Switzerland). After light microscopic examination, areas of interest were processed further for electron microscopy.

Imaging and quantitation. Sections were viewed on a Leica epifluorescence microscope using N2 (TRITC), L3 (FITC), and polarization filter blocks combined with bright-field and/or dark-field illumination. Immunostaining and in situ hybridization were documented by photography using Ilford T-MAX film. Photographs were printed by hand or were generated digitally by scanning $35 \mathrm{~mm}$ negatives using a Nikon LS-1000 at 900-1300 pixels/inch, by composing using Adobe Photoshop, and by printing on a Sony UP-D8800 graphics printer at 300 pixels/inch. Gray levels were stretched to optimize contrast, but images were not filtered or otherwise manipulated.

The proportion of BDNF-expressing DRG cells was determined by counting the number of immunoreactive and nonimmunoreactive neuronal profiles in sections of DRG. In double-labeled sections, the percentage of BDNF-expressing cells expressing a second marker was assessed by switching between FITC, TRITC, and/or polarization filter blocks. At least 250 labeled DRG cells were examined for each marker and counted on randomly chosen DRG sections. With use of Visilog image analysis software, the cell size and level of expression of BDNF mRNA were assessed in trkA immunoreactive and immunonegative DRG cells using previously described methodology (Priestley et al., 1991). Images were captured directly off the microscope at $25 \times$ magnification using a Grundig FA87 digital camera with integrating framestore. Cells were then outlined manually using a computer mouse, and the area within each cell that was occupied by silver grains was calculated. At least 200 cells of each type were counted. The amount of BDNF immunostaining in lamina II of the spinal cord was also quantified, basically as described previously (Bennett el al., 1996a). Images were captured as above and thresholded to reveal 


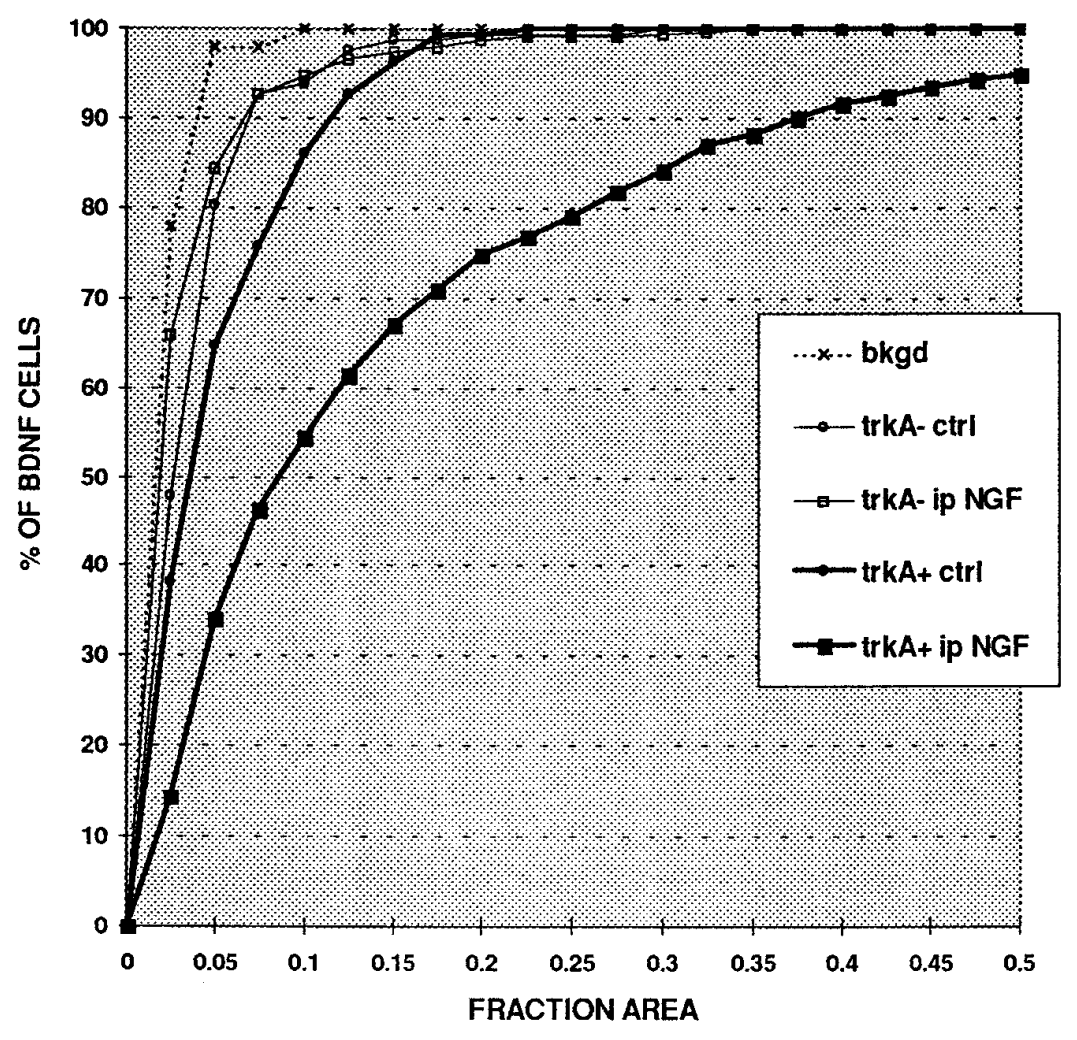

Figure 4. NGF increases BDNF mRNA expression only in trkA-immunoreactive cells as shown in $\mathrm{Q}$ sum plot of BDNF mRNA expression in trkA-immunoreactive $($ trkA +$)$ and trkA-nonimmunoreactive (trkA-) lumbar DRG cells in control (ctrl) and intraperitoneal NGF-treated (ip NGF) animals. BDNF expression was quantified by measuring the fraction of the cell body (FRACTION AREA) that was covered by silver grains. Note that intraperitoneal NGF does not change the level of BDNF expression in BDNF-labeled but trkA-nonimmunoreactive cells. In contrast intraperitoneal NGF greatly increases BDNF expression in trkA immunoreactive cells, and even in control animals these cells show higher labeling than the trkA nonimmunoreactive population. bkgd indicates the level of background labeling in control and NGF-treated animals.

\begin{tabular}{lcccc}
\hline Table 3. The percentage of BDNF mRNA expressing DRG cells that also exhibit trkB mRNA, trkC mRNA, or IB4 labeling \\
& $\%$ of BDNF expressing other & $\%$ of other expressing BDNF \\
\hline BDNF and trkB mRNAs & $1 \%(2 / 175)$ & & $2.4 \%(2 / 83)$ & not trkA immunoreactive \\
& trkA immunoreactive & not trkA immunoreactive & trkA immunoreactive & no \\
& $8 \%(13 / 166)$ & $7 \%(11 / 166)$ & $10 \%(13 / 133)$ & $8 \%(11 / 133)$ \\
\hline BDNF and trkC mRNAs & $34 \%(71 / 208)$ & $15 \%(31 / 208)$ & $32 \%(71 / 221)$ & $14 \%(31 / 221)$ \\
BDNF mRNA and IB4 labelling & & & \\
\hline
\end{tabular}

Intraperitoneal NGF treatment.

BDNF terminals, the threshold level being kept constant for both control and NGF-treated animals. Several $27 \times 27 \mu \mathrm{m}$ measuring boxes were placed over each image, and the area within each box that was occupied by immunostained terminals was calculated; $120-240$ areas were sampled for each animal.

\section{RESULTS}

\section{NGF effects on BDNF protein and BDNF mRNA in lumbar ganglia}

In lumbar ganglia of control rats, BDNF immunoreactivity was evident in DRG cells and occasional axons. The quality of staining, however, varied between animals, depending on the immunocytochemical staining method. Thus few cells were stained using indirect immunofluorescence, whereas good TSA fluorescence preparations (Fig. 1a) showed staining in $\sim 22 \%$ of DRG cells. Rats treated with intraperitoneal NGF showed a similar quality and range of BNDF immunostaining but little change in the number of immunoreactive DRG cells (Fig. 1c, Table 1). In contrast, ganglia from animals treated intrathecally with NGF showed abundant and robust BDNF immunostaining (Fig. 1e). As many as $40 \%$ of DRG cells showed immunoreactivity (Table $1)$, together with numerous axons. In all types of preparation, staining was confined to DRG cells and adjoining axons. Thus there was no indication of staining within satellite cells or Schwann cells.

In situ hybridization for BDNF mRNA showed a pattern of staining similar to that observed for BDNF protein. Thus a few heavily labeled DRG cells were observed in control animals together with numerous cells showing labeling slightly above background (Fig. 1b). The intraperitoneal NGF-treated animals (Fig. $1 d$ ) and the intrathecally treated animals (Fig. 1f) both showed increased labeling compared with controls. However, the total number of labeled cells increased only slightly (Table 1), suggesting that the increased in situ hybridization labeling represented mainly an increase in grain density per cell.

\section{Relationship between BDNF expression and trkA expression in lumbar ganglia}

The NGF effects were characterized further by combining BDNF immunocytochemistry with immunofluorescence for trkA or CGRP. BDNF immunoreactivity was present mainly in trkA cells, but the extent of double-labeling varied according to the type of NGF treatment (Fig. $2 a-d$, Table 2). For example, the percentage of trkA-immunoreactive cells that were BDNF immunoreactive increased from $21 \%$ in controls (Fig. $2 a, b$ ) to $84 \%$ after intrathecal NGF (Fig. $2 c, d$ ). NGF also increased the double- 


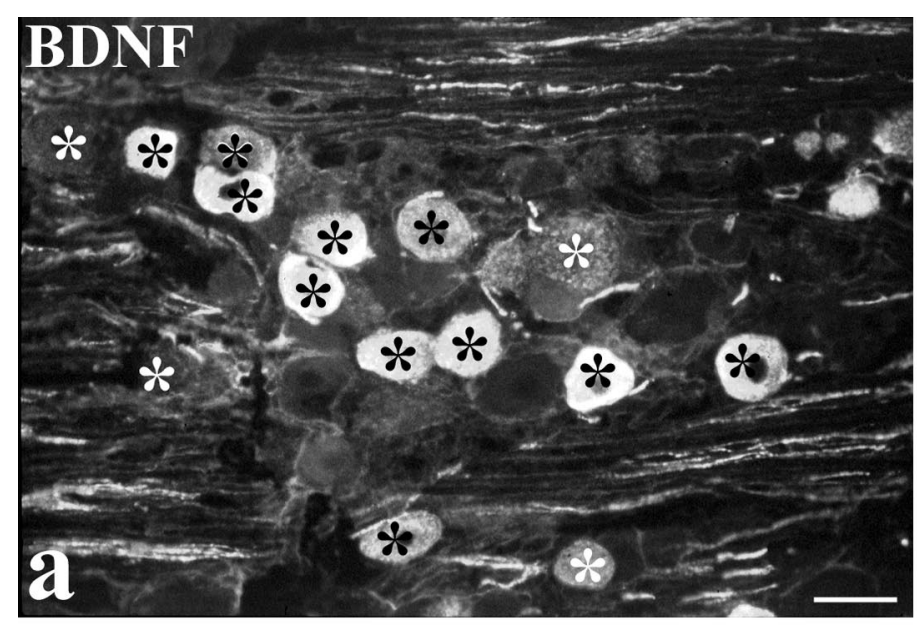

\section{trkA.mRNA.}
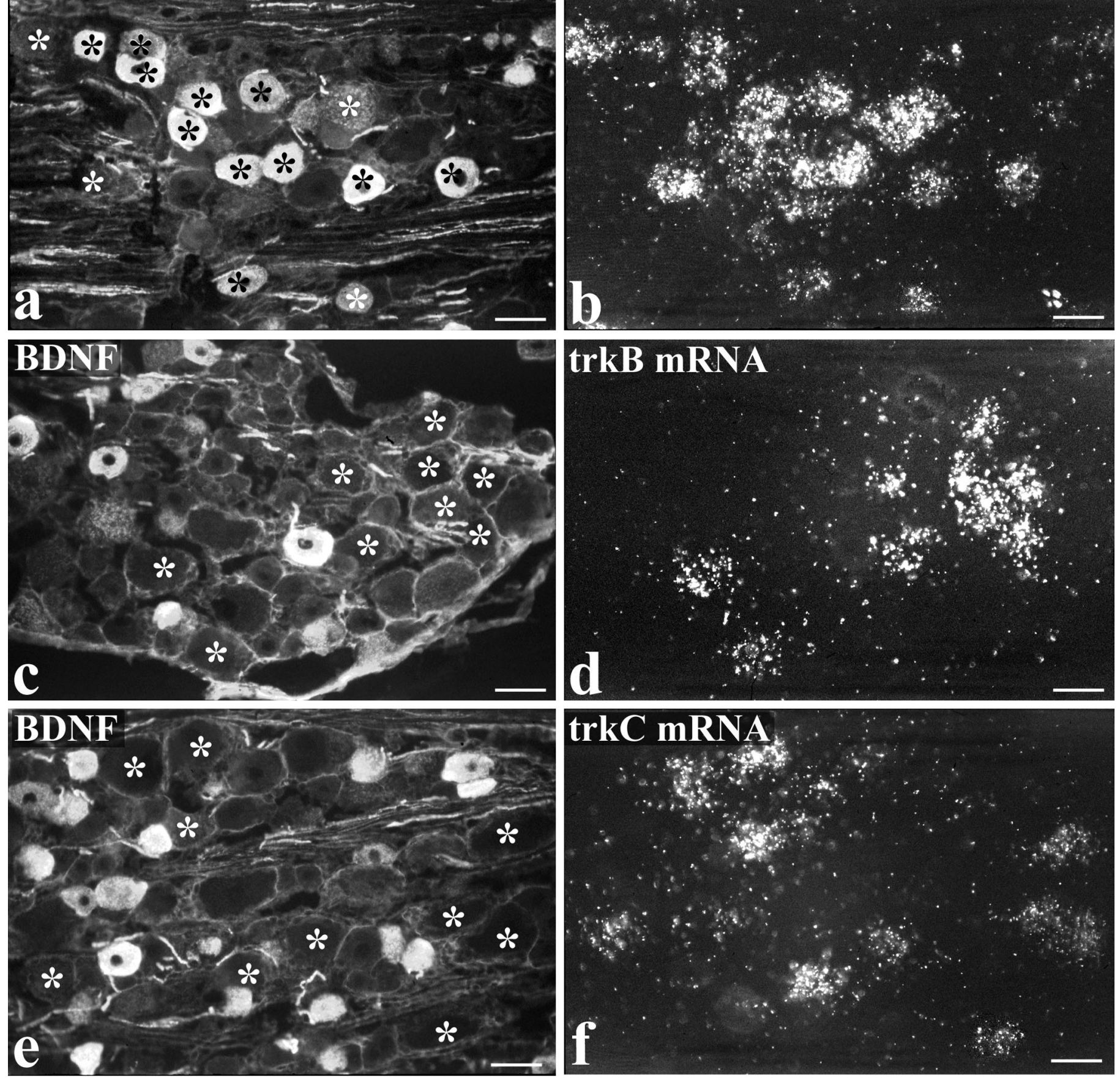

Figure 5. Intrathecal NGF treatment. BDNF immunoreactivity is present in numerous trkA cells but in few trkB or trkC cells. $a-f$ show preparations double-labeled for BDNF immunoreactivity $(a, c, e)$ and either $\operatorname{trkA}(b), \operatorname{trkB}(d)$, or $\operatorname{trkC}(f)$ in situ hybridization. The asterisks indicate the location of trk-expressing cells, revealed by the in situ hybridization autoradiograms. Many BDNF-immunoreactive cells show trkA labeling $(a, b)$, but the trkBand trkC-expressing cells are distinct from the BDNF-immunoreactive ones. Scale bars, $50 \mu \mathrm{m}$.

labeling in terms of the percentage of BDNF cells that were trkA immunoreactive (Table 2). Very similar results were obtained for CGRP, consistent with previous studies showing that CGRP labels broadly the same DRG subpopulation as trkA (Averill et al., 1995). Thus extensive coexistence of BDNF and CGRP immunoreactivities was observed (Fig. 2e,f), and this coexistence varied according to the type of NGF treatment in the same way as the trkA/BDNF coexistence (Table 2).
To determine whether the BDNF protein observed in trkA/ CGRP cells was locally synthesized, BDNF in situ hybridization was also combined with trkA immunofluorescence (Fig. $3 c, d$, Table 2). Just as with BDNF protein, extensive overlap was observed between BDNF mRNA and trkA, and the degree of coexistence increased with NGF treatment. Thus $30 \%$ of trkAimmunoreactive cells expressed BDNF mRNA in controls, whereas this figure increased to $88 \%$ after intrathecal NGF (Ta- 
Table 4. The percentage of BDNF-immunoreactive DRG cells that also express trkA, trkB, or trkC mRNA

\begin{tabular}{lll} 
& $\begin{array}{l}\% \text { of BDNF } \\
\text { expressing trk }\end{array}$ & $\begin{array}{l}\% \text { of trk } \\
\text { expressing BDNF }\end{array}$ \\
\hline BDNF and trkA mRNA & $85 \%(583 / 684)$ & $82 \%(583 / 706)$ \\
BDNF and trkB mRNA & $2.5 \%(18 / 708)$ & $9.5 \%(18 / 179)$ \\
BDNF and trkC mRNA & $6 \%(53 / 842)$ & $13 \%(53 / 399)$
\end{tabular}

Intrathecal NGF treatment. The figures in brackets indicate the number of cells counted.

ble 2). To exclude the possibility that these changes in $\mathrm{BDNF} /$ trkA double-labeling were caused by changes in trkA expression, the effect of NGF on trkA immunoreactivity was also examined. The percentage of DRG cells that were trkA immunoreactive was not significantly affected by NGF treatment (Table 1).

Judged on the basis of either immunocytochemistry or in situ hybridization, a proportion of BDNF-expressing cells were not trkA immunoreactive (Figs. 2, 3; Table 2). Image analysis of preparations double-labeled for BDNF in situ hybridization and trkA immunofluorescence was performed to quantify the extent of labeling for BDNF mRNA in the trkA-immunoreactive and trkA-nonimmunoreactive cells and to quantify the effect of intraperitoneal NGF on the two populations. Consistent with the impression given by micrographs (e.g., Fig. $3 c, d$ ), this analysis showed that the trkA-immunoreactive cells had greater labeling for BDNF mRNA than the non-trkA cells and that intraperitoneal NGF greatly increased the degree of labeling in the trkA subpopulation (Fig. 4). In addition, it revealed that intraperitoneal NGF had no effect on the degree of BDNF mRNA labeling in the non-trkA cell population (Fig. 4) and had no effect on the cell-size distribution of the trkA subpopulation (data not shown).

\section{Relationship between BDNF expression and trkB or trkC expression in lumbar ganglia}

To determine the relationship between BDNF and trkB or trkC expression, two different methods of double-labeling were performed. The first method was used for animals treated with intraperitoneal NGF. Serial sections were processed for trkC, BDNF, and trkB in situ hybridization, and each section was also immunostained for trkA (Fig. 3). The trkA/BDNF doublelabeled sections were also stained with the lectin Griffonia simplicifolia IB4, a marker that has been proposed to mainly label DRG cells that do not express any known trk (Averill et al., 1995; Molliver et al., 1995; Silos-Santiago et al., 1995). This approach allowed us to determine whether BDNF-synthesizing cells belonged to the trkB, trkC, or non-trk (IB4) populations and also revealed whether labeled cells coexpressed trkA. A small overlap was seen between BDNF and both the trkC and IB4 populations. Thus $15 \%$ of BDNF mRNA-expressing cells were labeled for trkC mRNA, of which half were also trkA immunoreactive (Fig. $3 a, b$, Table 3 ). In addition, $49 \%$ of BDNF mRNA-expressing cells showed IB4 labeling (not illustrated), with approximately two thirds of these also trkA immunoreactive (Table 3 ). In contrast to trkC or IB4, however, there was virtually no overlap between BDNF mRNA and trkB. Only $1 \%$ of BDNF mRNA-expressing cells were also labeled for trkB mRNA (Fig. 3e,f, Table 3).

The second method of double-labeling was applied to animals treated intrathecally with NGF and involved BDNF immunofluorescence combined with trkA, trkB, or trkC in situ hybridization (Fig. 5). This allowed a direct analysis of whether BDNF protein was present in trkB- or trkC-expressing cells, as well as providing an additional assessment of the degree of BDNF/trkA coexpression. Consistent with the other labeling methods, a high percentage of trkA mRNA-expressing cells were BDNF immunoreactive $(82 \%)$ (Table 4). A small percentage of BDNF-immunoreactive cells expressed trkC mRNA $(6 \%)$, and an even smaller percentage expressed trkB (3\%) (Table 4).

\section{BDNF axonal transport}

To determine whether BDNF was axonally transported to or from lumbar dorsal root ganglia, BDNF immunoreactivity was examined at the site of dorsal root (Fig. 6a,b) and sciatic (Fig. $6 e, f)$ ligations. The accumulation of BDNF immunoreactivity was compared with that of trkA (Fig. $6 c, d$ ) and CGRP (Fig. $6 g, h$ ) immunoreactivities. In dorsal roots, BDNF transport seemed to be mainly anterograde. BDNF immunoreactivity accumulated predominantly proximal to a dorsal root ligation (i.e., the DRG side). In contrast, both anterograde and retrograde transport of trkA was evident. TrkA immunoreactivity accumulated both proximal and distal to the ligation but with greater accumulation proximal rather than distal (Fig. $6 a-d$ ). In the sciatic nerve, both anterograde and retrograde transport of BDNF were detected. BDNF immunoreactivity accumulated both proximal (DRG side) and distal to a sciatic ligation (Fig. 6e,f). The proximal accumulation was generally greater than that distally, and on both sides of the ligation the majority of BDNF-immunoreactive axons were also CGRP immunoreactive (Fig. $6 e-h$ ). The BDNF accumulation in dorsal roots and sciatic nerve was greater after intraperitoneal NGF than in control animals, and in the case of double ligatures no accumulation was seen in the isolated portion of nerve between the ligatures (not illustrated). The footpad and dorsal surface of the foot were examined for peripherally transported BDNF. Immunoreactivity was present but was confined to light staining of fiber bundles in the dermis and of isolated axons in the epidermis (not illustrated).

\section{BDNF immunoreactivity in the spinal cord}

BDNF immunoreactivity was examined in the lumbar cord of control (Fig. 7a,b), intraperitoneal NGF-treated (not illustrated), and intrathecal NGF-treated (Figs. $7 c, d$ ) animals. BDNF immunoreactive axons and terminals were observed mainly in the central projections of small diameter primary afferents. Terminals were particularly abundant in the superficial dorsal horn (laminae I, II) (Figs. 7a,c), in patches in deep dorsal horn (Fig. 7c,e), and dorsolateral to the central canal (Fig. $7 \mathrm{~g}$ ). In all of these regions, BDNF showed extensive coexistence with CGRP (Figs. 7e- $h$ ), such that BDNF-immunoreactive axons that lacked CGRP immunoreactivity were rarely observed. In contrast to CGRP, BDNF-immunoreactive terminals did not coexist with IB4 (not illustrated). As with the staining in DRG, the extent of BDNF immunoreactivity in spinal cord varied, depending on whether animals had been treated with NGF. Control and intrathecal NGF-treated animals were easily distinguished. After intrathecal NGF, BDNF-immunoreactive terminals were more abundant (compare Fig. 7, $a$ and $c$ ), and more extensive coexistence with CGRP was seen. After intrathecal delivery of NGF to the cervical cord, the BDNF immunoreactivity in primary afferents was so intense that it was possible to trace axons from the ganglion into the dorsal horn (Fig. 8). Staining in intraperitoneal NGF-treated animals was not as great as in intrathecally treated animals, and there was significant interanimal variability. In general, however, 

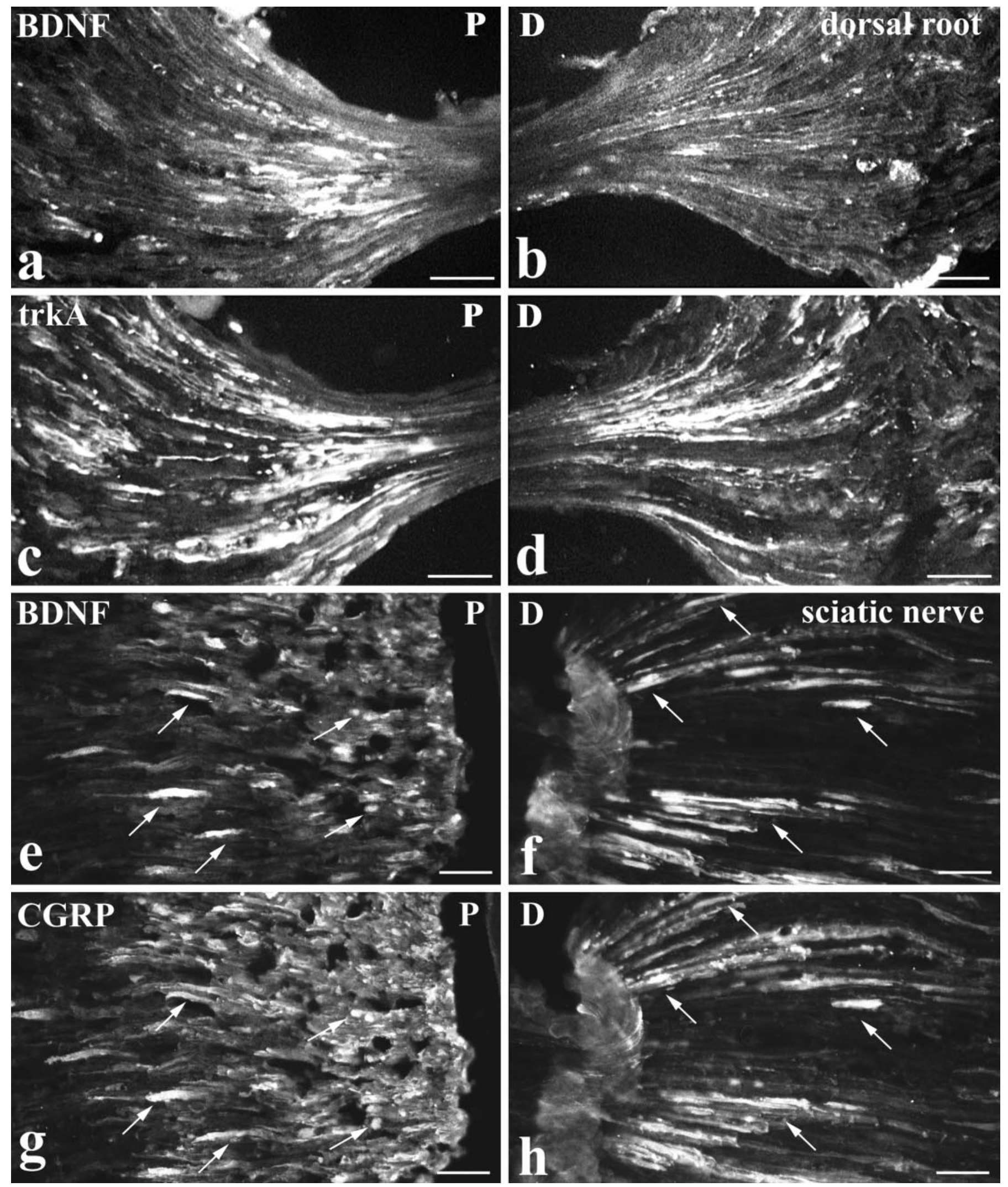

Figure 6. Intraperitoneal NGF treatment. BDNF is anterogradely transported. BDNF $(a, b, e, f)$, trkA $(c, d)$, and CGRP $(g, h)$ immunoreactivity proximal $(P: a, c, e, g)$ and distal $(D: b, d, f, h)$ to lumbar dorsal root $(a-d)$ or sciatic nerve $(e-h)$ ligations are shown. At a dorsal root ligation, both BDNF $(a)$ and trkA $(c)$ accumulate proximal to the ligation (i.e., the DRG side). Distal to the ligation, trkA immunoreactivity accumulates $(d)$ but only occasional BDNF-immunoreactive axons are visible $(b)$. At a sciatic nerve ligation, BDNF accumulates both proximal $(e)$ and distal $(f)$ to the ligation. CGRP shows a similar accumulation $(g, h)$, and double-staining reveals that the BDNF-immunoreactive axons are also CGRP immunoreactive (arrows indicate double-labeled axons). Scale bars, $50 \mu \mathrm{m}$. 

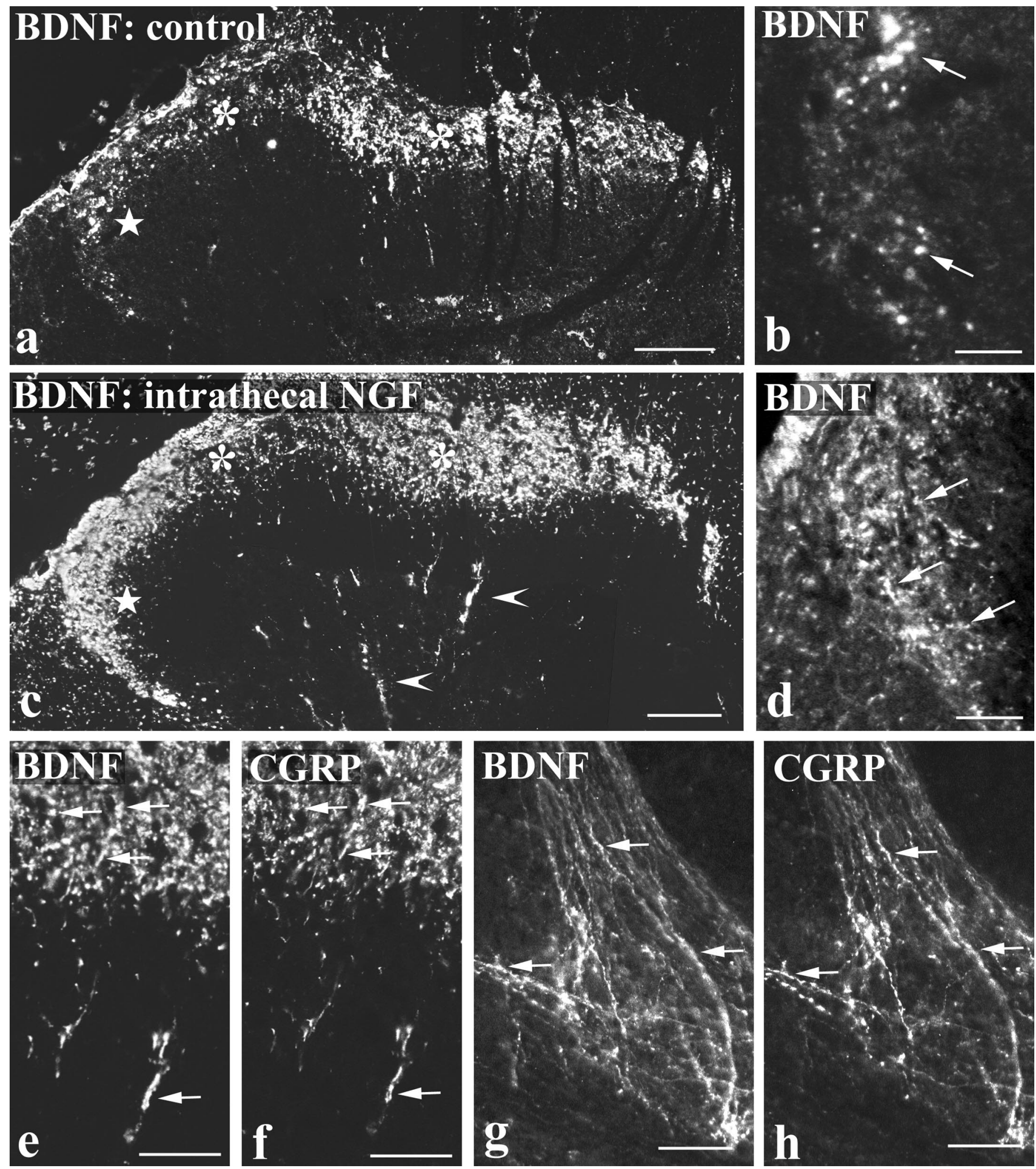

Figure 7. BDNF immunoreactivity in the spinal cord is increased by NGF treatment and is present in CGRP-immunoreactive axons. $a-d$ show BDNF immunofluorescence in the dorsal horn of control tissue $(a, b)$ and after intrathecal NGF treatment $(c, d)$. BDNF immunoreactivity in laminae I and II (asterisks in $a$ and $c$ ) and in deep dorsal horn (arrowheads in $c$ ) is increased by NGF. The increase is particularly striking in lateral lamina II (stars in $a$ and $c$ ), and this region is shown at high magnification in $b$ and $d$. Immunoreactive axons (arrows in $b$ and $d$ ) are more abundant after NGF treatment. $e-h$, Double-labeling showing extensive coexistence of BDNF $(e, g)$ and CGRP $(f, h)$ after intrathecal NGF treatment. In the dorsal horn $(e, f)$ and in lamina X dorsolateral to the aqueduct $(g, h)$, numerous double-labeled axons and varicosities (arrows) are visible. Scale bars: $a, c, 100 \mu \mathrm{m} ; b, d, 25 \mu \mathrm{m}$; $e-h, 50 \mu \mathrm{m}$. 


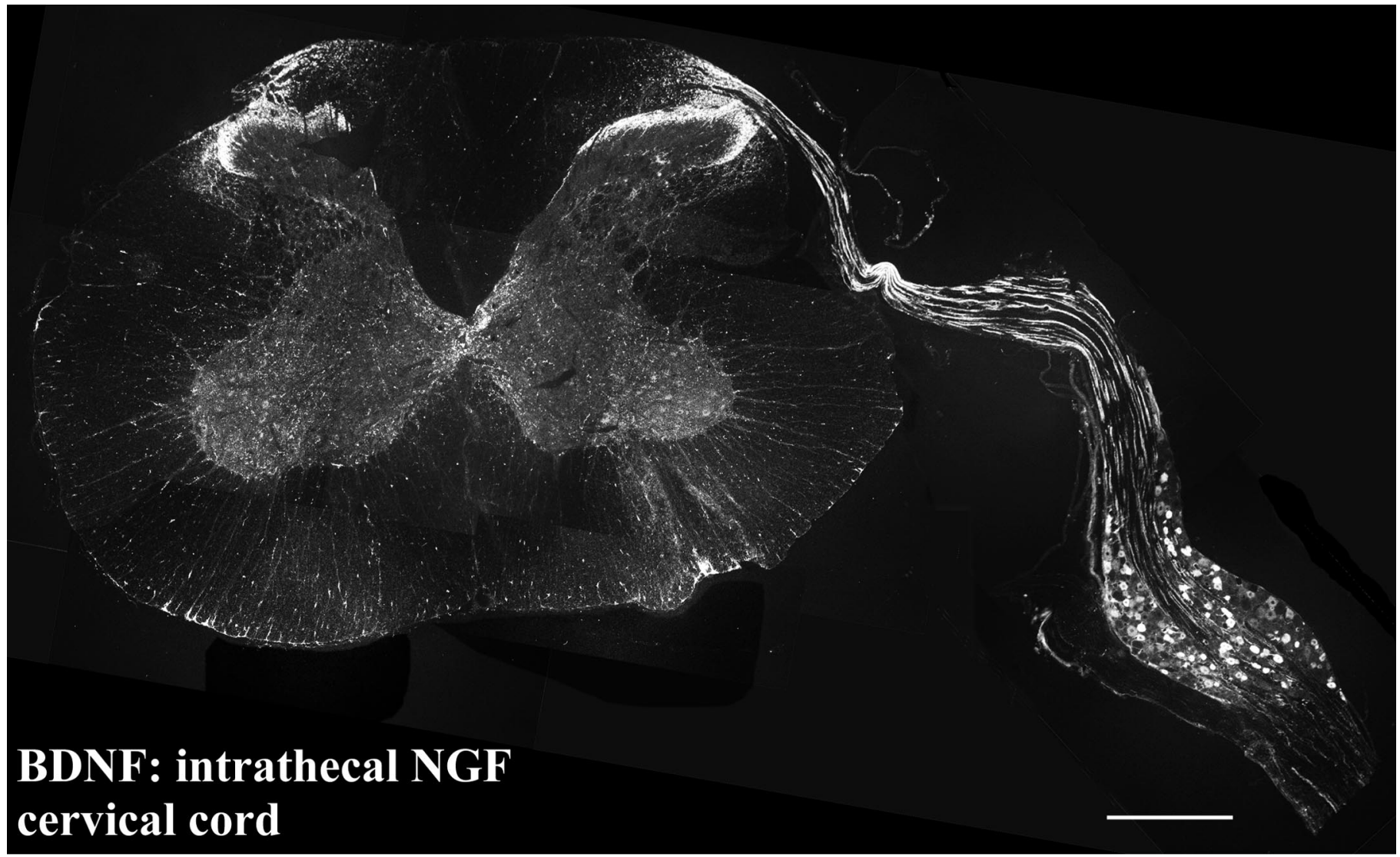

Figure 8. Photomontage of a transverse section showing the cervical spinal cord and attached DRG of an animal treated intrathecally with NGF via an upper cervical cannula. BDNF protein is transported by DRG cells along their central processes and into the spinal cord. BDNF levels have increased to such an extent that immunoreactive axons can be traced from DRG cells, along a dorsal root and into the dorsal horn of the spinal cord. Scale bar, $250 \mu \mathrm{m}$.

it seemed to be slightly greater than in controls, and this was confirmed by image analysis. The mean staining level of BDNFimmunoreactive terminals in lamina II of intraperitoneal NGFtreated animals was twice that obtained in control animals.

\section{Ultrastructural localization of BDNF immunoreactivity in the dorsal horn}

Immunoreactive unmyelinated axons (Fig. 9b), finely myelinated axons (Fig. 9c), and axon terminals (Fig. 9a) were observed in lamina II. Immunoreactive terminals included characteristic sinuous terminals that made asymmetric synapses and displayed an electron-dense axoplasm containing several large dense-cored vesicles and numerous agranular vesicles (Fig. 9a). In heavily stained terminals, the immunoreaction deposit filled the axoplasm and covered dense-cored vesicles and the membranes of agranular vesicles. In lightly stained terminals, the reaction deposit had a more restricted distribution and seemed to be concentrated over a subpopulation of dense-cored vesicles (Fig. 9c).

\section{DISCUSSION}

In this study we have shown that trkA-expressing DRG cells synthesize BDNF and anterogradely transport it to axon terminals within the spinal cord. BDNF levels are modulated by NGF, with intrathecally administered NGF having much more potent effects than systemic NGF. In addition we have shown that a small number of DRG cells that do not express trkA also synthesize BDNF but that BDNF mRNA in these cells is not increased by NGF. Such cells include trkC cells and cells that do not express any of the trks, but very few trkB cells. The expression of BDNF protein in DRG cells matches very closely the expression of BDNF mRNA. These results have profound implications for our understanding of BDNF function in sensory neurons.

\section{DRG subgroups that synthesize BDNF}

Previous studies have described BDNF mRNA (Ernfors et al., 1990, 1993; Wetmore and Olson, 1995; Apfel et al., 1996; Cho et al., 1997) or protein (Wetmore and Olson, 1995; Zhou and Rush, 1996) in adult rat DRG cells, and two studies have recently reported that some cells expressing BDNF mRNA also express trkA mRNA (Apfel et al., 1996; Cho et al., 1997). We have extended these studies by fully characterizing the expression of both BDNF mRNA and protein in relation to all of the trkexpressing subpopulations of DRG cells.

Our results show that BDNF is synthesized by several different DRG subtypes, but the biggest contribution comes from cells that express trkA and the neuropeptide CGRP (Fig. 10). TrkAimmunoreactive cells in control animals have higher levels of BDNF mRNA than non-trkA-immunoreactive cells, and after intrathecal NGF, BDNF and trkA/CGRP identify virtually identical populations. Of the BDNF-expressing cells, 80-90\% belong to the trkA group, and almost $90 \%$ of trkA cells express BDNF mRNA. This close correspondence between BDNF and the trkA/CGRP group is echoed in the spinal cord, where BDNF immunoreactivity in both control and NGF-treated animals is confined to CGRP containing primary afferents. BDNF is absent 

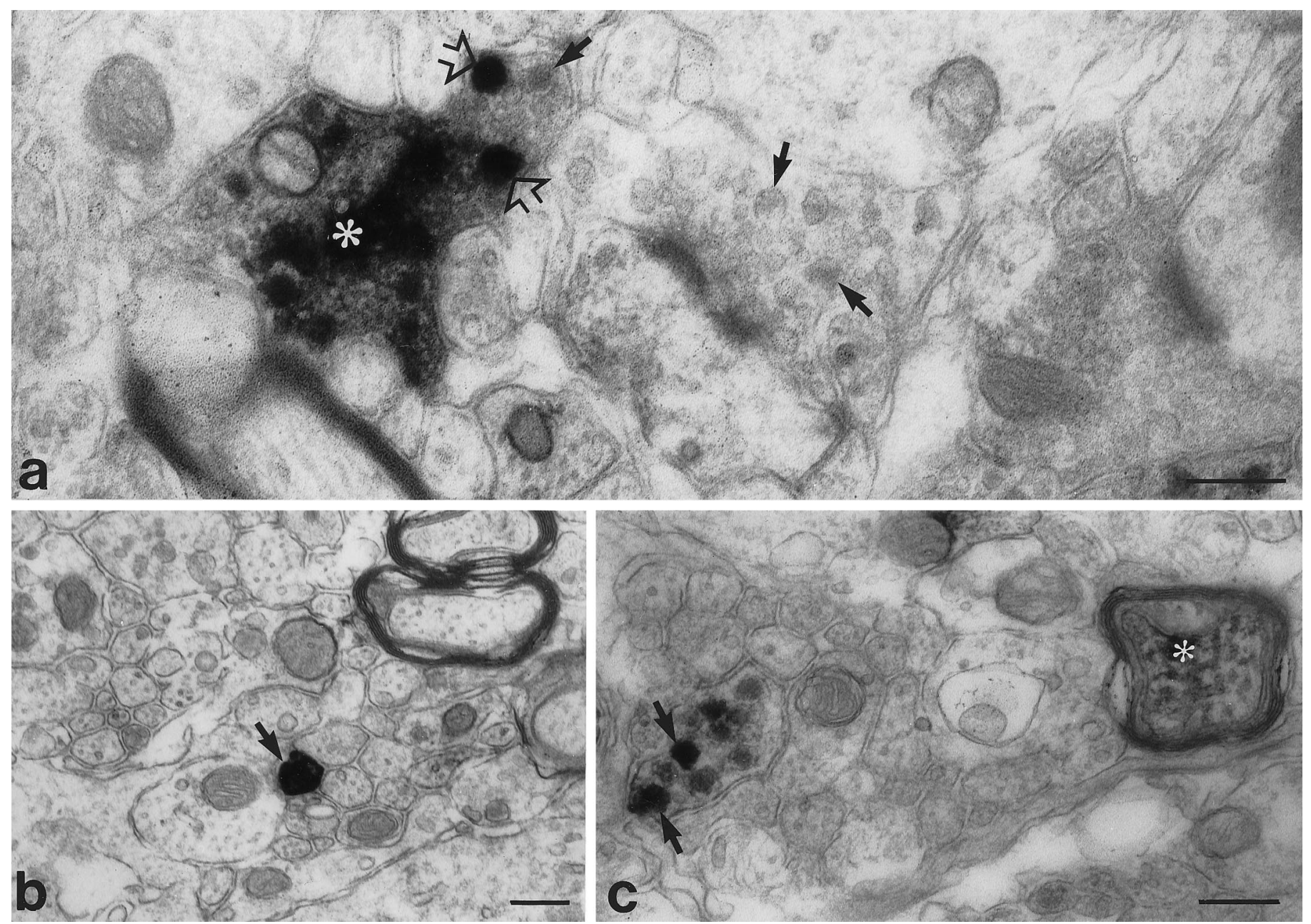

Figure 9. Preembedding ultrastructural immunocytochemistry showing BDNF immunoreactivity in axons $(b, c)$ and an axon terminal $(a)$ in lamina II of the lumbar spinal cord. $a$, An immunoreactive terminal (asterisk) shows heavy staining over a region packed with small agranular vesicles and over individual large dense-cored vesicles (open arrows). Arrows indicate dense-cored vesicles in an adjoining unstained terminal. $b$, A heavily stained unmyelinated axon (arrow) is visible among a group of similar, but unstained, axons. $c$, An immunostained preterminal axon and an immunostained finely myelinated axon (asterisk) are visible. The preterminal axon shows staining exclusively over large dense-cored vesicles (arrows). Scale bars, $0.25 \mu$ m.

from the termination zones of large-diameter afferents and of IB4-labeled afferents, consistent with our data showing that relatively few trkC- or IB4-labeled cells express BDNF mRNA. However, the fact that these cell types express some BDNF may be significant. NGF increases BDNF expression selectively in trkA-immunoreactive cells (discussed below), but it is possible that BDNF in the non-trkA population is affected by other factors. For example, BDNF expression in DRG cells is increased by nerve damage (Ernfors et al., 1993), and we have shown recently that this occurs at least partly in trkC cells (Averill et al., 1997). In vitro, a BDNF autocrine loop has been shown to mediate the survival of a subpopulation of adult DRG cells (Acheson et al., 1995). Our results, however, indicate that in vivo there is very little coexistence of BDNF and trkB mRNAs. Only $1 \%$ of cells expressing BDNF mRNA also expressed trkB, and only $2 \%$ of trkB cells contained BDNF mRNA. The simplest interpretation of this data is that an autocrine loop does not occur in control or NGF-supplemented adult animals. However, our data do not rule out the possibility that an autocrine loop occurs in certain circumstances. Axonal damage may upregulate BDNF in trkB cells, or BDNF may support survival of trkA cells in some way that does not involve trkB. We also cannot exclude the possibility that some BDNF cells express trkB at levels below our detection threshold. Consistent with other recent studies (Kashiba et al., 1995; Wright and Snider, 1995; McMahon et al., 1997), we observed minimal overlap between trkA and trkB cells (Fig. 10). However, extensive overlap of trkA and trkB has been described (McMahon et al., 1994) and may be attributable to low-level trkB expression in some trkA cells.

Our preparations showed good BDNF immunostaining, with BDNF mRNA and protein generally in rather similar numbers and types of cells. After NGF, BDNF mRNA was observed in more cells than BDNF protein. However, this probably simply reflects the fact that a greater increase in BDNF expression was needed to bring cells above the detection threshold for immunocytochemistry than for in situ hybridization. In contrast to the extensive coexistence of BDNF and trkA, we observed very little BDNF protein in trkB cells. Only $10 \%$ of trkB-labeled cells showed BDNF immunoreactivity. This is a surprising result, given that target-derived BDNF is thought to be axonally transported by trkB-expressing DRG cells (DiStefano et al., 1992). However, our studies of BDNF axonal transport support our 


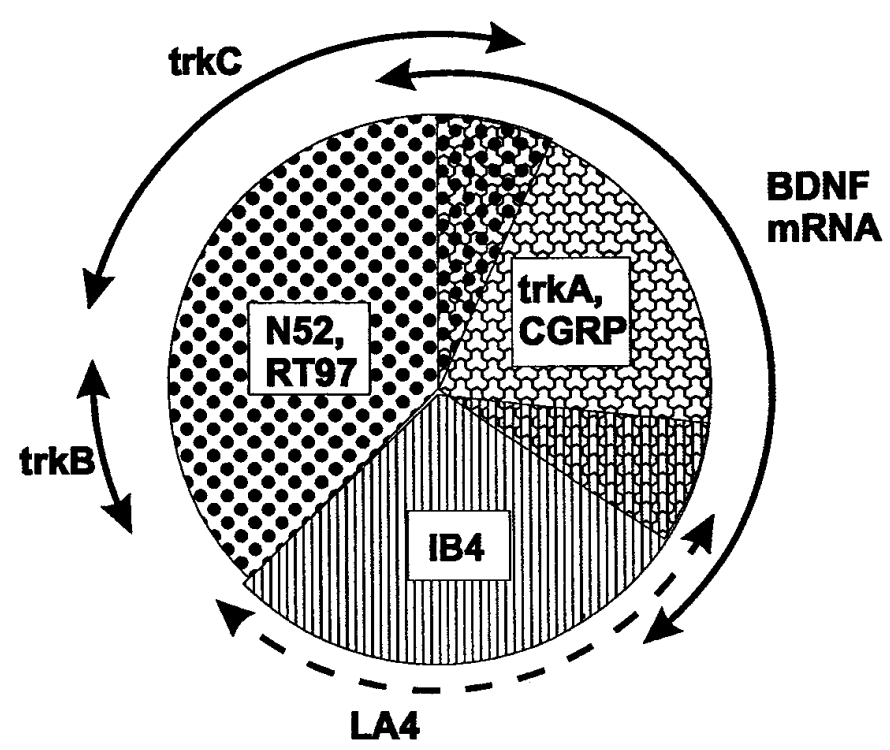

Figure 10. Pie chart summarizing the relationship between BDNF and trk expression in neurochemically defined DRG subclasses. DRG neurons can be divided broadly into large-diameter cells, which innervate lowthreshold mechanoreceptors, and small-diameter cells, which innervate mainly nociceptors. BDNF mRNA is expressed by the subpopulation of small cells that contain the neuropeptide CGRP and the NGF receptor trkA. Small cells that do not express any trk receptor, and that can be labeled using the lectin Griffonia simplicifolia IB4 or the monoclonal antibody LA4, mainly do not express BDNF. With the exception of those trkC cells that coexpress trkA, BDNF mRNA is also largely not expressed by trkB or trkC cells. TrkC and trkB are present mainly in large-diameter cells, which can be identified using the neurofilament antisera N52 or RT97. BDNF is constitutively expressed in the cell types illustrated, but expression in trkA cells is increased further by NGF treatment.

localization data in indicating that there is little retrograde BDNF transport. BDNF immunoreactivity accumulated distal to a sciatic ligation but showed extensive colocalization with CGRP, implying that it represents mainly recycling of anterogradely transported protein. BDNF may be present in trkB cells at levels below our detection threshold, but if so it must be at levels that are much lower than those that occur in trkA cells. It thus seems that most BDNF protein in DRG cells is synthesized locally, with target-derived BDNF making only a small contribution.

\section{Upregulation of BDNF by NGF and its functional consequences}

In addition to detecting BDNF protein within trkA/CGRP immunoreactive DRG cell bodies, we observed that BDNF in these cells is (1) anterogradely transported along both their central and peripheral processes and (2) present in the spinal cord in all their terminal fields, and that (3) immunoreactivity is concentrated over dense-cored vesicles. Biochemical studies have recently shown that BDNF in cortex is enriched in a vesicular fraction of synaptosomes (Fawcett et al., 1997). Our ultrastructural results are consistent with this work and indicate that dense-cored vesicles are likely to be the primary site of BDNF storage. NGF treatment led to a massive increase of both mRNA and protein, with increased anterograde transport to central terminals. Anterograde transport of BDNF into the dorsal horn has also recently been reported by Zhou and Rush (1996), although the cell type responsible was not identified. Transport and axodendritic transfer of exogenous NT-3 has recently been reported in the developing visual system (von Bartheld et al., 1996), and BDNF-immunoreactive terminals have been described in various CNS regions (Kawamoto et al., 1996; Conner et al., 1997; Yan et al., 1997), suggesting that anterograde transport may be widespread. Goodman and colleagues (1996) have demonstrated that BDNF in cultured cells colocalizes with the secretory granule marker chromogranin A and is released from hippocampal dendrites by a regulated pathway dependent on extracellular calcium (Goodman et al., 1996). BDNF release has not been demonstrated in vivo, but our observations make it highly likely that BDNF can be released from primary afferent terminals in the dorsal horn.

Our data on the effects of NGF are broadly in agreement with the recent study of Apfel and colleagues (1996) in showing that NGF upregulates BDNF mRNA in trkA-expressing DRG cells; however, there are some differences of detail. They observed no effect of chronic NGF treatment and interpreted the BDNF response as an acute reaction. In contrast, we observed that a 2 week intrathecal NGF infusion had a much more potent effect, indicating not only the increased efficacy of the intrathecal route but also that the BDNF increase is maintained. Primary afferents presumably normally respond to NGF, acting at their peripheral processes, and so the intrathecal route is not like the situation in vivo. However, effects after intrathecal and intraperitoneal or local nerve application are qualitatively similar (this study; also see Verge et al., 1996), suggesting that the intrathecal route is appropriate for examining DRG responses to trophic factors.

Apfel and colleagues (1996) also report that BDNF mRNA is increased in non-trkA expressing cells and interpret this as a paracrine interaction. In contrast we saw no change in this cell group. Quantitative analysis of the increase in BDNF mRNA after NGF indicated that it was restricted to the trkAimmunoreactive subpopulation, as might be expected if it involves direct activation of trkA receptors. A similar analysis was not performed after intrathecal NGF, so we cannot exclude the possibility that the intrathecal route increased BDNF in some nontrkA cells. However, the extensive overlap observed between trkA and BDNF after intrathecal NGF makes it unlikely.

Our data thus support neither an autocrine nor a paracrine role for BDNF within DRG, but do support a role as an anterograde trophic messenger. Such a role has been described in late embryonic development (Robinson et al., 1996) and may be maintained, or adapted, into adult life. Many trkA-expressing DRG cells are nociceptive, and increased NGF in inflammation has both acute and chronic effects on pain processing (McMahon, 1996; Woolf, 1996). We have shown that exogenous NGF increases BDNF expression in trkA cells, and Cho et al. (1997) have recently shown that similar changes take place after peripheral inflammation. BDNF released from primary afferent terminals may therefore play a key role in chronic pain states by modulating dorsal horn activity in various ways. Full length trkB receptors are present in the dorsal horn (G. J. Michael and J. V. Priestley, unpublished observations), and BDNF applied to the spinal cord increases c-fos and nitric oxide synthase in dorsal horn neurons (Bennett et al., 1996b). BDNF may also have effects on spinal cord anatomy and on expression of neurotransmitter receptors. These possibilities are being investigated.

\section{REFERENCES}

Acheson A, Conover JC, Fandl JP, DeChlara TM, Russell M, Thadani A, Squinto SP, Yancopoulos GD, Lindsay RM (1995) A BDNF 
autocrine loop in adult sensory neurons prevents cell death. Nature 374:450-453.

Apfel SC, Wright DE, Wiideman AM, Dormia C, Snider WD, Kessler JA (1996) Nerve growth-factor regulates the expression of brain-derived neurotrophic factor messenger RNA in the peripheral nervous system. Mol Cell Neurosci 7:134-142.

Averill S, McMahon SB, Clary DO, Reichardt LF, Priestley JV (1995) Immunocytochemical localization of trkA receptors in chemically identified subgroups of adult rat sensory neurons. Eur $\mathrm{J}$ Neurosci 7:1484-1494.

Averill S, Michael GJ, Shortland PJ, Priestley JV (1997) BDNF increases in large diameter dorsal root ganglion cells and in their central projections following peripheral axotomy. Soc Neurosci Abstr 23:134.8.

Bennett DLH, French J, Priestley JV, McMahon SB (1996a) NGF but not NT-3 or BDNF prevents the A fibre sprouting into lamina II of the spinal cord that occurs following axotomy. Mol Cell Neurosci 8:211-220.

Bennett DLH, French JS, Priestley JV, McMahon SB (1996b) The effects of BDNF on c-fos and NOS expression in dorsal horn neurones of the adult rat spinal cord. Soc Neurosci Abstr 22:396.15.

Cho HJ, Kim SY, Park MJ, Kim DS, Kim JK, Chu MY (1997) Expression of mRNA for brain-derived neurotrophic factor in the dorsal root ganglion following peripheral inflammation. Brain Res 749:358-362.

Clary DO, Weskamp G, Austin LAR, Reichardt LF (1994) TrkA crosslinking mimics neuronal responses to nerve growth factor. Mol Biol Cell 5:549-563.

Conner JM, Lauterborn JC, Yan Q, Gall CM, Varon S (1997) Distribution of brain-derived neurotrophic factor (BDNF) protein and mRNA in the normal adult rat CNS: evidence for anterograde axonal transport. J Neurosci 17:2295-2313.

Curtis R, Adryan KM, Stark JL, Park JS, Compton DL, Weskamp G, Huber LJ, Chao MV, Jaenisch R, Lee KF, Lindsay RM, DiStefano PS (1995) Differential role of the low-affinity neurotrophin receptor (p75) in retrograde axonal-transport of the neurotrophins. Neuron 14:1201-1211.

DiStefano PS, Friedman B, Radziejewski C, Alexander C, Boland P, Schick CM, Lindsay RM, Wiegand SJ (1992) The neurotrophins BDNF, NT-3, and NGF display distinct patterns of retrograde axonal transport in peripheral and central neurons. Neuron 8:983-993.

Ernfors P, Wetmore C, Olson L, Persson H (1990) Identification of cells in rat brain and peripheral tissues expressing mRNA for members of the nerve growth factor family. Neuron 5:511-526.

Ernfors P, Rosario CM, Merlio JP, Grant G, Aldskogius H, Persson H (1993) Expression of mRNAs for neurotrophin receptors in the dorsal root ganglion and spinal cord during development and following peripheral or central axotomy. Mol Brain Res 17:217-226.

Fawcett JP, Aloyz R, Mclean JH, Pareek S, Miller FD, McPherson PS, Murphy RA (1997) Detection of brain-derived neurotrophic factor in a vesicular fraction of brain synaptosomes. J Biol Chem 272: $8837-8840$.

Goodman LJ, Valverde J, Lim F, Geschwind MD, Federoff HJ, Geller AI, Hefti F (1996) Regulated release and polarized localization of brain-derived neurotrophic factor in hippocampal neurons. Mol Cell Neurosci 7:222-238

Hunt SP, Mantyh PW, Priestley JV (1992) The organization of biochemically characterized sensory neurons. In: Sensory neurons. Diversity, development, and plasticity (Scott SA, ed), pp 60-76. New York: Oxford UP.

Hunyady B, Krempels K, Harta G, Mezey E (1996) Immunohistochemical signal amplification by catalyzed reporter deposition and its application in double immunostaining. J Histochem Cytochem 44:1353-1362.

Kashiba H, Noguchi K, Ueda Y, Senba E (1995) Coexpression of trk family members and low-affinity neurotrophin receptors in rat dorsalroot ganglion neurons. Mol Brain Res 30:158-164.

Kawamoto Y, Nakamura S, Nakano S, Oka N, Akiguchi I, Kimura J (1996) Immunohistochemical localization of brain-derived neurotrophic factor in adult rat brain. Neuroscience 74:1209-1226.

Lawson SN (1992) Morphological and biochemical cell types of sensory neurons. In: Sensory neurons. Diversity, development, and plasticity (Scott SA, ed), pp 27-59. New York: Oxford UP.

Maness LM, Kastin AJ, Weber JT, Banks WA, Beckman BS, Zadina JE (1994) The neurotrophins and their receptors: structure, function, and neuropathology. Neurosci Biobehav Rev 18:143-159.
Mannion RJ, Doubell TP, Coggeshall RE, Woolf CJ (1996) Collateral sprouting of uninjured primary afferent A-fibers into the superficial dorsal horn of the adult rat spinal cord after topical capsaicin treatment to the sciatic-nerve. J Neurosci 16:5189-5195.

McMahon SB (1996) NGF as a mediator of inflammatory pain. Philos Trans R Soc Lond [Biol] 351:431-440.

McMahon SB, Armanini MP, Ling LH, Phillips HS (1994) Expression and coexpression of trk receptors in subpopulations of adult primary sensory neurons projecting to identified peripheral targets. Neuron 12:1161-1171.

McMahon SB, Bennett DLH, Michael GJ, Priestley JV (1997) Neurotrophic factors and pain. In: Progress in pain research and management, Vol 8 (Jensen TS, Turner JA, Wiesenfeld-Hallin Z, eds). Seattle: IASP Press, in press.

Meakin SO, Suter U, Drinkwater CC, Welcher AA, Shooter EM (1992) The rat trk protooncogene product exhibits properties characteristic of the slow nerve growth factor receptor. Proc Natl Acad Sci USA 89:2374-2378.

Merighi A, Polak JM, Gibson SJ, Gulbenkian S, Valentino KL, Peirone SM (1988) Ultrastructural studies on calcitonin gene-related peptideimmunoreactive, tachykinin-immunoreactive and somatostatinimmunoreactive neurons in rat dorsal root ganglia: evidence for the colocalization of different peptides in single secretory granules. Cell Tissue Res 254:101-109.

Michael GJ, Priestley JV (1995) Expression of GAP-43 messenger-RNA in preganglionic sympathetic neurons of the adult rat spinal cord. NeuroReport 7:338-342.

Michael GJ, Priestley JV (1996a) Expression of trkA and p75 low affinity nerve growth factor receptors in the adrenal gland. NeuroReport 7:1617-1622.

Michael GJ, Priestley JV (1996b) Combined immunocytochemistry and in situ hybridization. In: In situ hybridization techniques for the brain (Henderson Z, ed), pp. 111-118. Chichester: Wiley.

Middlemas DS, Lindberg RA, Hunter T (1991) TrkB, a neural receptor protein-tyrosine kinase: evidence for a full-length and two truncated receptors. Mol Cell Biol 11:143-153.

Molliver DC, Radeke MJ, Feinstein SC, Snider WD (1995) Presence or absence of trkA protein distinguishes subsets of small sensory neurons with unique cytochemical characteristics and dorsal horn projections. J Comp Neurol 361:404-416.

Priestley JV (1997) Immunocytochemical techniques for the study of the nervous system. In: Neurochemistry: a practical approach, 2nd ed (Bachelard H, Turner A, eds), pp 71-120. Oxford: Oxford UP.

Priestley JV, Réthelyi M, Lund PK (1991) Semi-quantitative analysis of somatostatin mRNA distribution in the rat central nervous system using in situ hybridization. J Chem Neuroanat 4:131-153.

Priestley JV, Alvarez FJ, Averill S (1992) Pre-embedding electron microscopic immunocytochemistry. In: Electron microscopic immunocytochemistry (Polak JM, Priestley JV, eds), pp 89-121. Oxford: Oxford UP.

Priestley JV, Wotherspoon G, Savery D, Averill S, Rattray M (1993) A combined in situ hybridization and immunofluorescence procedure allowing visualisation of peptide mRNA and serotonin in single sections. J Neurosci Methods 48:99-110.

Priestley JV, Michael GJ, Averill S, Nitkunan A, Wotherspoon G, Rattray M, Bennett DLH, Yan Q, McMahon SB (1996) NGF treatment increases BDNF expression in trkA immunoreactive dorsal root ganglion cells and in their central terminations within the spinal cord. Soc Neurosci Abstr 22:223.8.

Robinson M, Bujbello A, Davies AM (1996) Paracrine interactions of BDNF involving NGF-dependent embryonic sensory neurons. Mol Cell Neurosci 7:143-151.

Shindler KS, Roth KA (1996) Double immunofluorescent staining using two unconjugated primary antisera raised in the same species. J Histochem Cytochem 44:1331-1335.

Silos-Santiago I, Molliver DC, Ozaki S, Smeyne RJ, Fagan AM, Barbacid M, Snider WD (1995) Non-trkA-expressing small DRG neurons are lost in trkA deficient mice. J Neurosci 15:5929-5942.

Timmusk T, Palm K, Metsis M, Reintam T, Paalme V, Saarma M, Persson H (1993) Multiple promoters direct tissue-specific expression of the rat BDNF gene. Neuron 10:475-489.

Valenzuela DM, Maisonpierre PC, Glass DJ, Rojas E, Nunez L, Kong Y, Stitt TN, Ip N Y, Yancopoulos GD (1993) Alternative forms of rat TrkC with different functional capabilities. Neuron 10:963-974. Verge VMK, Gratto KA, Karchewski LA, Richardson PM (1996) Neu- 
rotrophins and nerve injury. Philos Trans R Soc Lond [Biol] 351:423-430.

von Bartheld CS, Byers MR, Williams R, Bothwell M (1996) Anterograde transport of neurotrophins and axodendritic transfer in the developing visual system. Nature 379:830-833.

Wetmore C, Olson L (1995) Neuronal and nonneuronal expression of neurotrophins and their receptors in sensory and sympathetic ganglia suggest new intercellular trophic interactions. J Comp Neurol 353:143-159.

Woolf CJ (1996) Phenotypic modification of primary sensory neurons: the role of nerve growth factor in the production of persistent pain. Philos Trans R Soc Lond [Biol] 351:441-448.
Woolf CJ, Shortland P, Coggeshall RE (1992) Peripheral nerve injury triggers central sprouting of myelinated afferents. Nature 355:75-78.

Wright DE, Snider WD (1995) Neurotrophin receptor mRNA expression defines distinct populations of neurons in rat dorsal root ganglia. J Comp Neurol 351:329-338.

Yan Q, Rosenfeld RD, Matheson CR, Hawkins N, Lopez OT, Bennett L, Welcher AA (1997) Expression of brain-derived neurotrophic factor (BDNF) protein in the adult rat central nervous system. Neuroscience 78:431-448.

Zhou XF, Rush RA (1996) Endogenous brain-derived neurotrophic factor is anterogradely transported in primary sensory neurons. Neuroscience 74:945-951. 